\title{
UM COMUNICADO E UM CONVITE
}

RAIMAR RICHERS

Qualquer iniciativa inédita enfrenta uma série de incógnitas e riscos de difícil previsão. No caso do lançamento de uma nova publicação, a pergunta crucial é necessàriamente aquela que se refere ao grau de receptividade por parte dos possíveis leitores.

Nada sabiamos a êsse respeito quando entrou em circulação o primeito número da Revista de Administração de Emprêsas. Arriscamo-nos - e tivemos sorte: os leitores aceitaram e, ao que parece, aprovaram a idéia, pois diàriamente recebemos novas solicitaçôes de assinaturas.

Apesar disso, confessamos conhecer pouco nossas leitores e seu modo de encarar a publicação e seus artigos. Falta-nos um intercâmbio mais intenso com os que nos lêem.

Resolvemos, pois, adotar duas medidas: editar a Revista com maior freqüência e abrit nossas colunas aos leitores.

Com êste terceiro e último número do Volume 2, a Revista de Administração de Emprêsas passa a ser editada trimestralmente. Ainda no ano em curso, publicaremos 3 números (7, 8 e 9) que formarão o Volume 3. De 1964 em diante, os lançamentos dos volumes - com 4 números trimestrais cada um - obedecerão ao ano do calendário.

Queremos, ainda, formular um convite aos nossos leitores: escrevam a esta redação (Av. Paulista, 548, São Pau1o) sôbre assuntos relativos a artigos publicados. Esperamos, desta maneira, incentivar uma discussáo que nos estimule, esclareça e aproxime. 